Ozone $\left(\mathrm{O}_{3}\right)$ is a controversial gas because, owing to its potent oxidant properties, it exerts damaging effects on the respiratory tract and yet it has been used for four decades as a therapy. While the disinfectant activity of $\mathrm{O}_{3}$ is understandable, it is less clear how other biological effects can be elicited in human blood with practically no toxicity. On the other hand plasma and cells are endowed with a powerful antioxidant system so that a fairly wide range of $\mathrm{O}_{3}$ concentrations between 40 and $80 \mu \mathrm{g} / \mathrm{ml}$ per gram of blood $(-0.83-1.66 \mathrm{mM})$ are effective but not deleterious. After blood ozonation total antioxidant status (TAS) and plasma protein thiol groups (PTG) decrease by $20 \%$ and $25 \%$, respectively, while thiobarbituric acid reactive substances (TBARS) increases up to fivefold. The increase of haemolysis is negligible suggesting that the erythrocyte membrane is spared at the expense of other sacrificial substrates. While there is a clear relationship between the ozone dose and IL-8 levels, we have noticed that high TAS and PTG values inhibit the cytokine production. This is in line with the current idea that hydrogen peroxide, as a byproduct of $\mathrm{O}_{3}$ decomposition, acts as a messenger for the cytokine induction.

Key words: Ozone, Plasma oxidation, Antioxidants, Protein thiol groups, Interleukin-8

\section{Studies on the biological effects of ozone: 8. Effects on the total antioxidant status and on interleukin-8 production}

\author{
V. Bocci, ${ }^{1, C A}$ G. Valacchi, ${ }^{1}$ F. Corradeschi ${ }^{1}$ and \\ G. Fanetti ${ }^{2}$
}

${ }^{1}$ Institute of General Physiology, University of Siena, Via Laterina 8, 53100 Siena; ${ }^{2}$ Blood Bank-Azienda Ospedaliera Senese, 53100 Siena, Italy

\footnotetext{
${ }^{\mathrm{CA}}$ Corresponding Author Tel: (+39) 577263855 Fax: (+39) 577263861

Email: fisgen@unisi.it
}

\section{Introduction}

In medicine ozone has been used for more than four decades ${ }^{1}$ but its application remains controversial mainly because ozone is potentially toxic ${ }^{2}$ and mechanisms of action remain only partly known. ${ }^{3}$ However, work carried out in our laboratory ${ }^{3-6}$ has contributed to clarify that ozone toxicity can be checked if its concentration, measured precisely by ultraviolet spectrophotometry, is not higher than $80 \mu \mathrm{g} / \mathrm{ml}$ per gram of blood $(-1.76 \mathrm{mM})$.

Until recently it was thought that human blood should not be exposed to ozone concentrations higher than $35-40 \mu \mathrm{g} / \mathrm{ml}$ of gas $\left(\mathrm{O}_{2}+\mathrm{O}_{3}\right)$ per gram of blood. ${ }^{1}$ This was stated without any experimental basis and as our preliminary work has shown, haemolysis, as a simple marker of erythrocytic damage, becomes progressively relevant only when ozone concentration rises above $90 \mu \mathrm{g} / \mathrm{ml}$ per gram blood. ${ }^{3}$

Ozonated autohaemotherapy $\left(\mathrm{O}_{3}-\right.$ AHT $)$ is a complementary medical procedure firstly described by Wehrli and Steinbart, ${ }^{7}$ and since 1954 it has been used in millions of patients in different pathologies with apparent clinical benefit. Simply, it consists of briefly exposing blood collected in a disposable autotransfusion glass bottle to $\mathrm{O}_{2}+\mathrm{O}_{3}$ where the latter gas represents at most $4 \%$ of the gaseous mix ture. The ozonated blood is thereafter reinfused into the donor without side effects.

We believe that if $\mathrm{O}_{3}-$ AHT has to become a relevant complementary therapy, we must define precisely the ozone therapeutic window in order to improve effectiveness and minimize toxicity. $\mathrm{O}_{3}$, being a very reactive gas, could be detrimental to blood cells if plasma did not possess an important antioxidant capability. $\mathrm{O}_{3}$, when dissolves in plasma, generates a cascade of reactive oxygen species (ROS), among which hydrogen peroxide $\left(\mathrm{H}_{2} \mathrm{O}_{2}\right),{ }^{2}$ not dissimilar from the constant production of ROS occurring in physiological conditions. ${ }^{8}$ It has been well established that animal plasmas are usually able to ne utralize the damaging action of ROS by a powerful and articulate antioxidant system composed of soluble compounds, ${ }^{9-11}$ protein thyol groups, namely albumin, ${ }^{12-14}$ other proteinaceous chelators and three key enzymes. ${ }^{15}$

The question arises, how effective is the antioxidant system of human blood in taming $\mathrm{O}_{3}$ reactivity? To answer this question we have now evaluated critical biochemical parameters in order to monitor their modification when blood is exposed to different $\mathrm{O}_{3}$ concentrations. Moreover we have investigated whether exposure of blood to $\mathrm{O}_{3}$ for $1 \mathrm{~min}$ is able to induce any cytokines. By using different experimental conditions, we have previously shown show that $\mathrm{O}_{3}$, 
as other oxidants, can induce the production of interferon (IFN- $\gamma)^{16}$ and tumour necrosis factor (TNF$\alpha) .{ }^{17}$ In line with previous data, ${ }^{18,19}$ we report now that $\mathrm{O}_{3}$ can induce the release of significant amounts of interleukin (IL-8) from normal human blood.

\section{Materials and methods}

\section{Blood samples}

Blood samples were taken from healthy male blood donors in the morning at the Blood Bank of Siena University. The donors were aged between 22 and 63 years (mean $38 \pm 20$ years) and they gave informed consent to participate in the study. Calciheparin $(30 \mathrm{U} / \mathrm{ml}$ blood) was used as an anticoagulant and blood samples were tested within an hour. Each sample was divided into four aliquots (usually $5 \mathrm{ml}$ each): the first aliquot was used for assessing baseline values, while equal volumes of either pure medical $\mathrm{O}_{2}$, or $\mathrm{O}_{2}-\mathrm{O}_{3}\left(\mathrm{O}_{3}\right.$ concentration $\left.40 \mu \mathrm{g} / \mathrm{ml}\right)$ or $\mathrm{O}_{2}-\mathrm{O}_{3}$ $(80 \mu \mathrm{g} / \mathrm{ml} /$ per gram of blood) were added to the second, third and fourth aliquot, respectively. After trying several procedures, we found that rapid rotation of the syringe (filled half with blood and half with gas) along its longitudinal ax is (about 80 cycles/ min) achieved the best mixing with minimal foaming. After $1 \mathrm{~min}$, the blood was recovered free of gas and was used for the following determinations.

\section{Biochemical determinations}

(a) Total antioxidant status (TAS) in plasma samples was carried out according to Rice-Evans and Miller. ${ }^{20}$

(b) Protein thiol groups (PTG) were measured in plasma according to $\mathrm{Hu}^{21}$ using procedure $1 \mathrm{w}$ ith 5,5'-dithio-bis (2-nitrobenzoic acid) (DTNB) dissolved in absolute methanol.

(c) The thiobarbituric acid (TBA) assay was carried out in plasma as described by Buege and Aust's method. ${ }^{22}$ Values (mM) are reported as TBA reactive substances.

(d) The haemoglobin determination was carried out using $20 \mu \mathrm{l}$ of original blood and an equal volume of plasma collected after the ozonation. Samples were mixed with $5 \mathrm{ml}$ of the cyanide-methahaemoglobin reagent (Sclavo Hemoglobin test kit). Optical density, read spectrophotometrically at $540 \mathrm{~nm}$, was converted to hae moglobin according to a standard curve and referred to as a percentage of total haemoglobin.

\section{Determination of cytokines}

After the addition of a sterile glucose solution to achieve a glucose plasma concentration of $8-9 \mathrm{mM}$, aliquots of all blood samples were layered on sterile tissue culture wells that were incubated in air- $-\mathrm{CO}_{2}$ (5\%) for 8 hours. After centrifugation plasma samples were kept at $-70^{\circ} \mathrm{C}$ until determinations of cytokines were carried out. Immunoassays of IL-8, IL 4 and IFN $\gamma$ were carried out using Cytoscreen immunoassay kits produced by Biosource Intern. All plasma samples were diluted 1:1 with the ap propriate diluent. A threecycle automatic washing was routinely performed. Negative plasma samples, in the absence or presence of haemoglobin, were spiked with the cytokine's standards to assess the reliability and precision of the various assays. Yields ranged between $93 \%$ and $105 \%$.

\section{Statistical analyses}

Results were expressed as the mean \pm SD and the data were analysed using the Student's $t$-test. A $P$ value less than 0.01 was considered significant.

\section{Results}

In preliminary experiments we explored whether TAS concentration varied after mixing the blood and gas phases. Rapid rotation of the syringe achieved the lowest decrease within $1 \mathrm{~min}$ after gas exposure. An unexpected finding was that TAS levels recovered very quickly in blood and not in the plasma obtained from the same blood sample (Fig. 1). This results may be explained by our previous finding ${ }^{23}$ that in ozonated plasma there is a rapid and progressive increase of $\mathrm{H}_{2} \mathrm{O}_{2}$ in plasma (up to about $28 \mathrm{mM}$ ) while

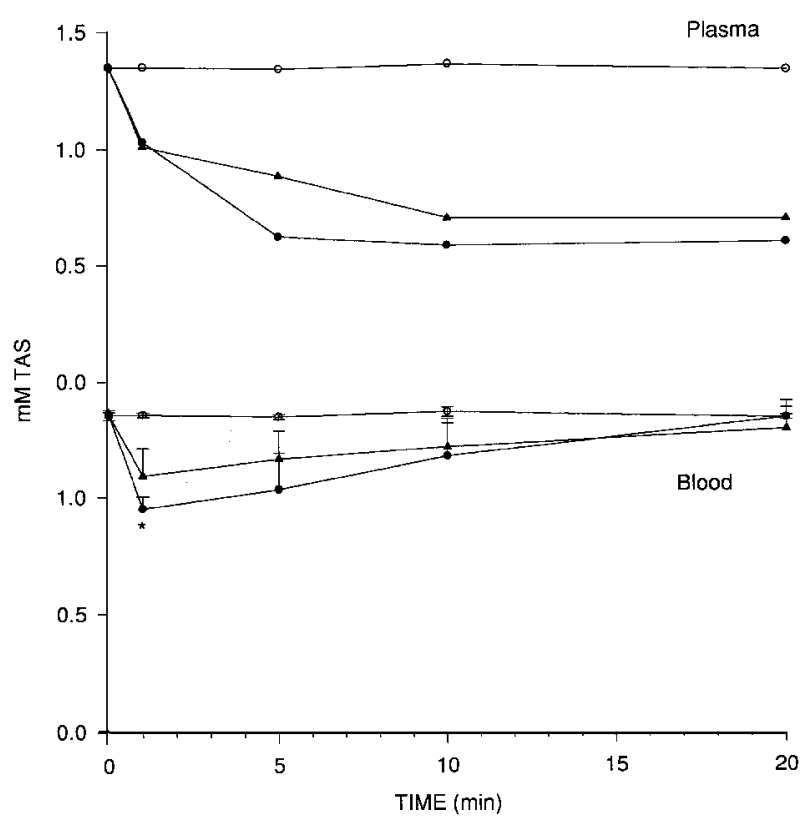

FIG. 1. Kinetics of total antioxidant levels in human plasma and blood after exposure at 0 time for $1 \mathrm{~min}$ of either $\mathrm{O}_{2}(\mathrm{O})$, or $\mathrm{O}_{3}(40 \mu \mathrm{g} / \mathrm{ml})(\boldsymbol{\Delta})$ or $\mathrm{O}_{3}(80 \mu \mathrm{g} / \mathrm{ml})(\boldsymbol{\theta})$. Upper level diagram: average of two experiments. Lower level diagram: mean \pm SD of four experiments. ${ }^{*}$ Significant difference $(P<$ 0.01) compared with control. 
it is hardly detectable in whole blood. Both TAS and PTG concentrations decrease after $\mathrm{O}_{3}$ exposure although the highest $\mathrm{O}_{3}$ concentration $(80 \mu \mathrm{g} / \mathrm{ml} / \mathrm{per}$ gram of blood) causes only either $20 \%$ or $25 \%$ decrease, respectively (Fig. 2). Conversely, TBARS levels and haemoglobin in plasma increased although the latter was barely perceptible (Fig. 3). Incubation of ozonated blood allowed the release of significant amounts of IL-8 (Fig. 4), whereas only negligible levels of IFN $-\gamma$ and IL 4 were detected. Figure 4 shows that in two blood samples (donors no. 3 and no. 12) IL-8 has not been induced at all. It is furthermore evident that increasing the $\mathrm{O}_{3}$ concentration from $40 \mu \mathrm{g} / \mathrm{ml}$ up to $80 \mu \mathrm{g} / \mathrm{ml}$ markedly enhances IL-8 release. Interestingly donors no. 3 and no. 12 had the highest TAS levels of all (1.8 and $1.9 \mathrm{mM}$, respectively). Donor no. 12 also had the highest levels of PTG $(0.54 \mathrm{mM})$. It appears therefore that a high level of antioxidants, by inhibiting the formation of $\mathrm{H}_{2} \mathrm{O}_{2}$, seems able to quench the oxidant activity of $\mathrm{O}_{3}$.

\section{Discussion}

The great reactivity of $\mathrm{O}_{3}$ and its inherent toxicity for biological structures has become orthodoxy in

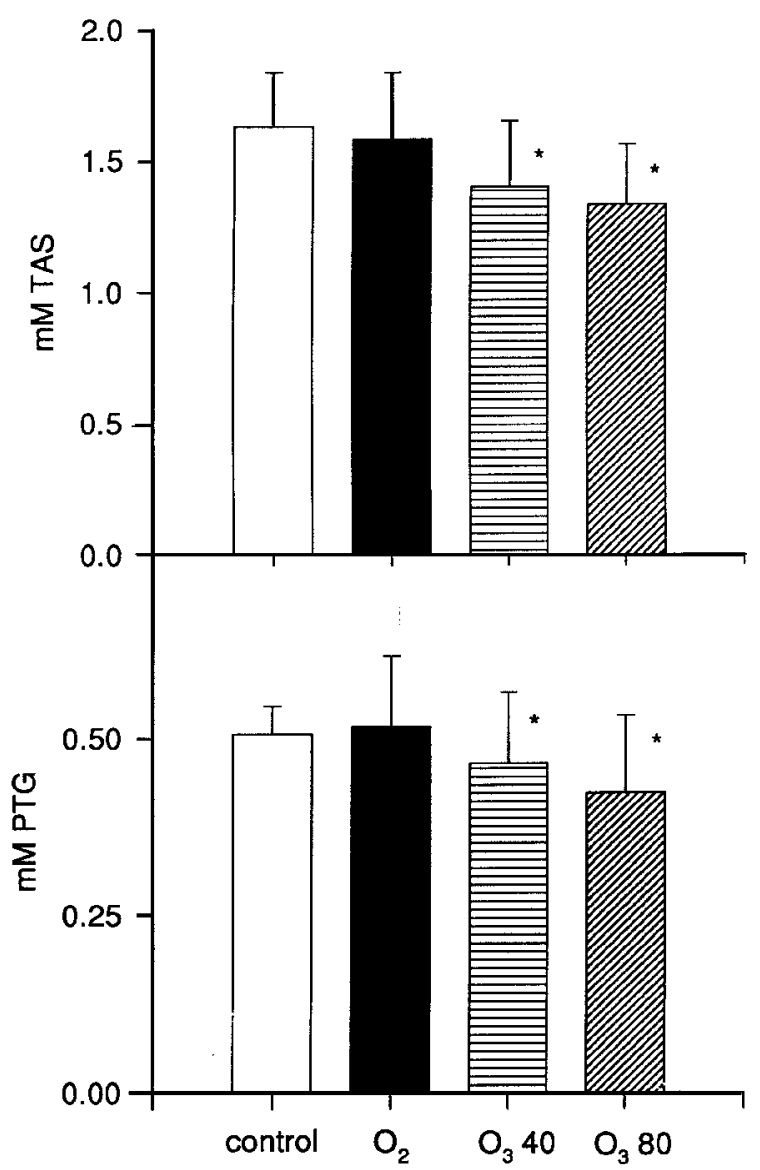

FIG. 2. Effect of $1 \mathrm{~min}$ exposure of either $\mathrm{O}_{2}$ or $\mathrm{O}_{3}(40 \mu \mathrm{g} / \mathrm{ml})$ or $\mathrm{O}_{3}(80 \mu \mathrm{g} / \mathrm{ml})$ on total antioxidant status (TAS) and protein thiol groups (PTG) of 13 blood samples. *Significant difference $(P<0.01)$ compared with control.

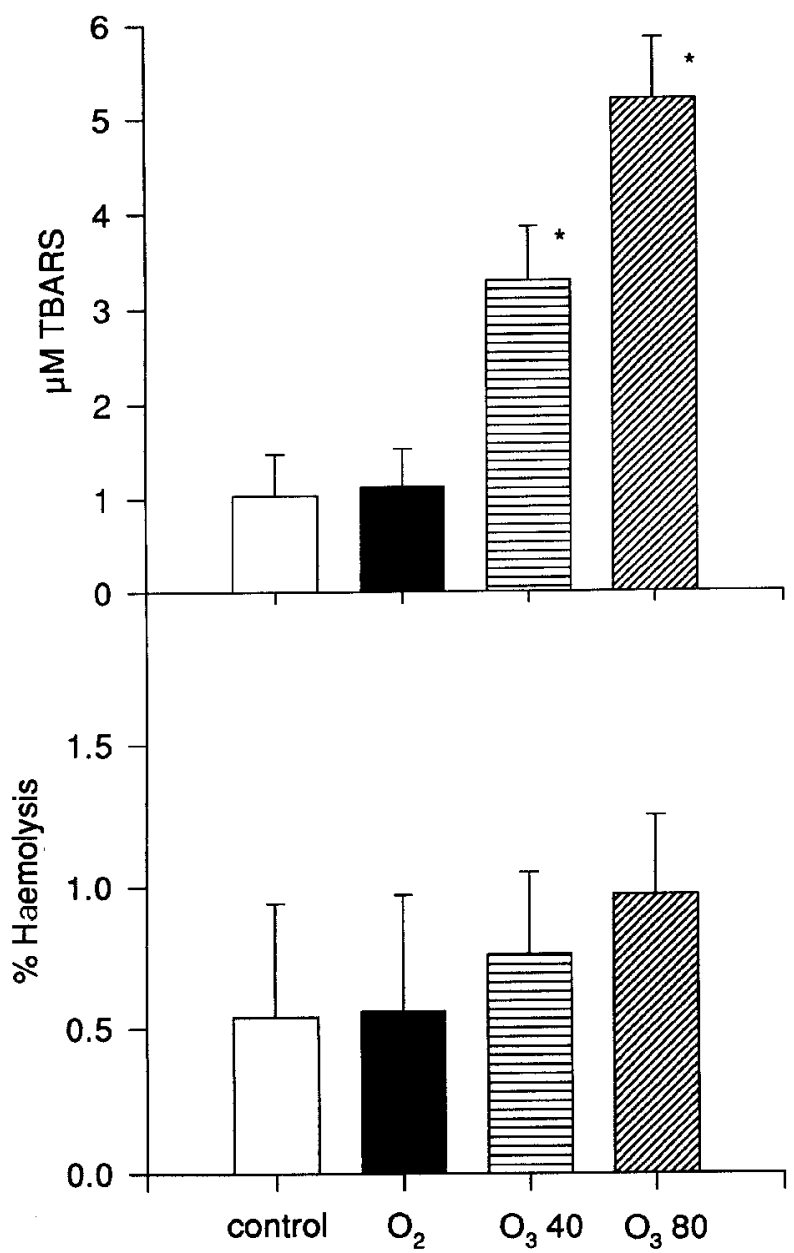

FIG. 3. Effect of $1 \mathrm{~min}$ exposure of either $\mathrm{O}_{2}$ or $\mathrm{O}_{3}(40 \mu \mathrm{g} / \mathrm{ml})$ or $\mathrm{O}_{3}(80 \mu \mathrm{g} / \mathrm{ml})$ on thiobarbituric acid reactive substances (TBARS) and haemolysis of the same 13 blood samples of Fig. 2. *Significant difference $(P<0.01)$ compared with control.

medicine. ${ }^{2,24}$ There are however two aspects that should not be overlooked: firstly, cells and organisms are endowed with a powerful and articulate antioxidant system $^{8-15}$ that may normally check the physiological production of oxidants; and secondly, that some oxidant molecules such as $\mathrm{H}_{2} \mathrm{O}_{2}$ and $\mathrm{NO}$ have been recently recognized as crucial physiological mediators. ${ }^{25,26}$ When human blood is exposed to $\mathrm{O}_{3}$, this gas dissolves in the plasmatic water and reacts immediately with several biomolecules, mainly polyunsaturated fatty acids generating $\mathrm{H}_{2} \mathrm{O}_{2}$ and an array of lipid oxidation products (LOP). ${ }^{2,27}$ Both $\mathrm{H}_{2} \mathrm{O}_{2}$ and LOP can elicit a number of biological effects on blood cells which, by displaying widely different functions, can also have different medical effects. The fundamental issues are that: firstly, $\mathrm{O}_{3}$ concentration must be precisely known and this is now possible with modern medical $\mathrm{O}_{3}$ generators; secondly, $\mathrm{O}_{3}$ concentration and gas volume must be accurately dosed in relation to blood weight; thirdly, that the dose of $\mathrm{O}_{3}$ must not be too low because it will be ineffective 


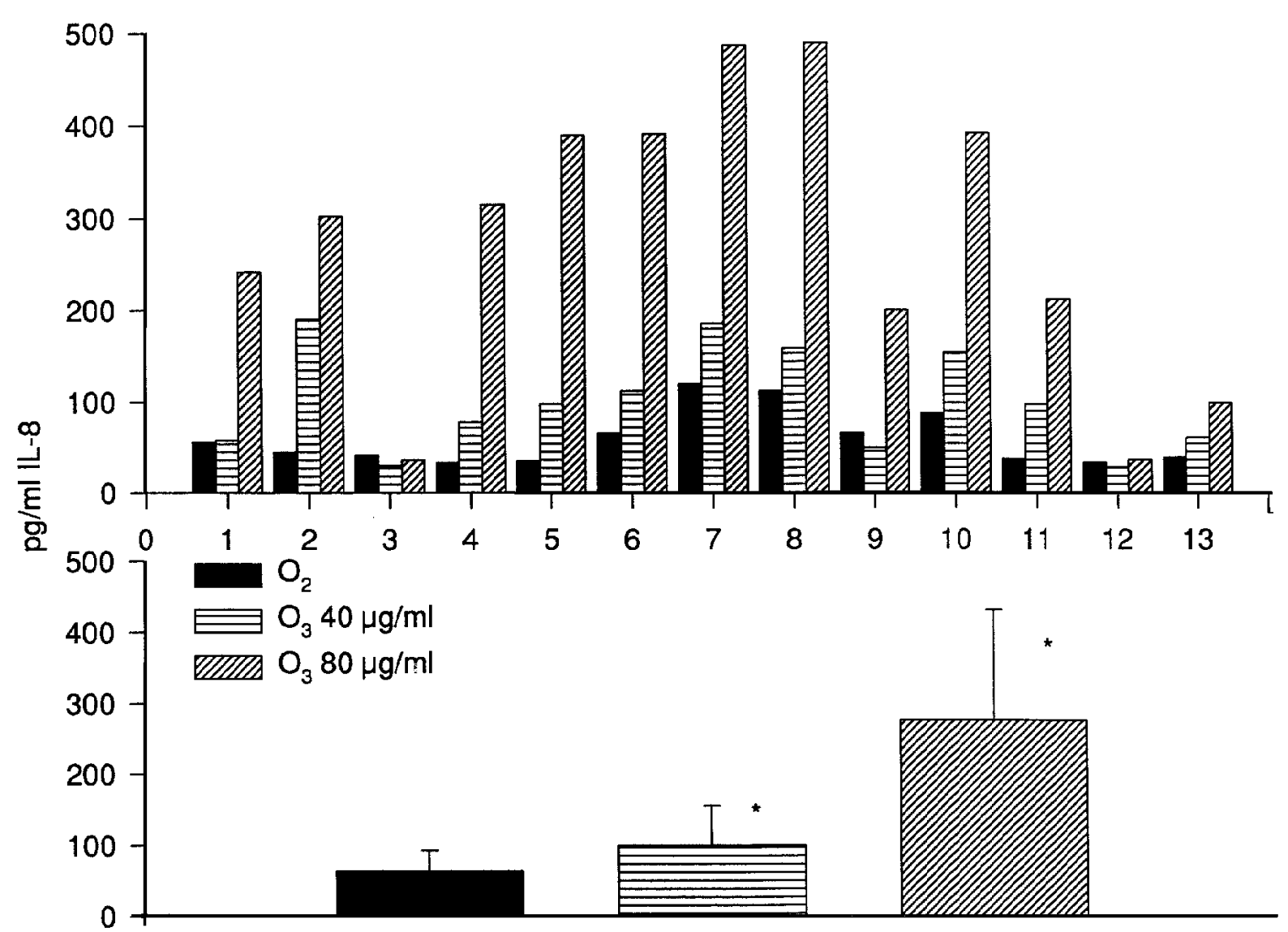

FIG. 4. Effect of $1 \mathrm{~min}$ exposure of either $\mathrm{O}_{2}$ or $\mathrm{O}_{3}(40 \mu \mathrm{g} / \mathrm{ml})$ or $\mathrm{O}_{3}(80 \mu \mathrm{g} / \mathrm{ml})$ on the production of IL-8 after 8-h incubation of the same 13 blood samples of Figs 2 and 3 . Average values are reported in the lower panel after subtracting control values. *Significant difference $(P<0.01)$ compared with samples treated with $\mathrm{O}_{2}$.

but not too high because it will be toxic. ${ }^{3}$ In other words, if we know the TAS and TPG levels of a blood sample, we can deliver an effective and atoxic ozone dose; if this view is accepted, ozone can be used as a real drug with a definite therapeutic window. Previous results and the data presented here indicate that for most human blood samples, acceptable $\mathrm{O}_{3}$ concentrations range between 30 and $80 \mu \mathrm{g} / \mathrm{ml}$ per gram of blood. Lower $\mathrm{O}_{3}$ concentrations may be almost totally quenched by the antioxidant system so that not enough $\mathrm{H}_{2} \mathrm{O}_{2}$ is generated to reach the threshold level for activating biochemical and immunological pathways.

We have now shown that even a very transient $\mathrm{O}_{3}$ exposure (only $1 \mathrm{~min}$ ) can allow the release of IL-8. Like Jaspers et al., ${ }^{19}$ we believe that induction of IL-8 by $\mathrm{O}_{3}$ is promoted by a transient rise of $\mathrm{H}_{2} \mathrm{O}_{2}$ in extracellular-cytoplasmic water via the activation of the nuclear factor (NF) $\mathrm{kB}$. This interpretation is well supported by previous data ${ }^{18}$ show ing inhibition of IL8 production in whole blood by ROS scavengers. IL- 8 is know $n$ to be an important chemokine able to initiate the chemotactic gradient that draws leukocytes from the circulation into tissues. In order to emphasize the typical double-edged sword activity of $\mathrm{O}_{3}$, it appears that when $\mathrm{O}_{3}$ acts on the human respiratory tract the influx of inflammatory cells into the airway lumen caused by IL- 8 can be detrimental, ${ }^{19}$ while reinfusion of ozonated blood in immunosuppressed patients can act as a use ful adjuvant in chronic viral diseases. ${ }^{3}$ At the present time, it remains unknown whether the ozonated blood can induce release of IL-8 in vivo although it appears unlikely as $\mathrm{O}_{3}$-AHT does not cause side effects. Moreover in our experimental conditions IL -4 and IFN- $\gamma$ were hardly detectable and this can be explained by a too short time of incubation as these cytokines are mostly produced after $70 \mathrm{~h} .{ }^{28} \mathrm{~A}$ final remark must be made about the negligible haemolysis (as a percentage) noticeable after blood exposure to $80 \mu \mathrm{g} / \mathrm{ml} \mathrm{O}_{3}$ : if the value due to mechanical stress is subtracted, oxidation is responsible for less than a $0.5 \%$ increase. This result emphasizes the great protective role of plasma because unphysiological situations like those used in the past, ${ }^{29,30}$ exposing washed erythrocytes suspended in saline media to $\mathrm{O}_{3}$ yielded considerable haemolysis. The present work has been instructive because it has convinced us that even if marker of peroxidation raises four-to five-folds, the re is no indication that the antioxidant system has been overw helmed with a resulting cell damage. Ozone therapy has been an empirical complementary procedure and unfortunately still is in the hands of quacks and of 
inexperienced practitioners with the implication that it is used either as a placebo or much worse as a tox ic therapy. We have now shown that simple tests can make ozonetherapy a reliable, reproducible and probably effective medical procedure.

\section{References}

1. Viebahn R. The use of Ozone in Medicine, 2nd ed. Heidelberg: Karl F. Haug Publishers, 1994; 1-178.

2. Pryor WA. Mechanisms of radical formation from reactions of ozone with target molecules in the lung. Free Radical Biol Med 1994; 17: 451-465.

3. Bocci V. Ozone as a bioregulator. Pharmacology and toxicology of ozonetherapy today. J Biol Regulat Homeost Agent 1996; 10: 31-53.

4. Bocci V, Luzzi E, Corradeschi F, Paulesu L, Di Stefano A. Studies on the biological effects of ozone: 3 . An attempt to define conditions for optimal induction of cytokines. Lymphokine Cytokine Res 1993; 12: 121-126.

5. Bocci V, Luzzi E, Corradeschi F, et al. Studies on the biological effects of ozone: 4. Cytokine production and glutathione levels in human erythrocytes. J Biol Regulat Homeost Agent 1993; 7: 133-138.

6. Bocci V, Luzzi E, Corradeschi F, Paulesu L. Studies on the biological effects of ozone: 5. Evaluation of immunological parameters and tolerability in normal volunteers receiving ambulatory autohaemotherapy. Biotherapy 1994; 7: 83-90.

7. Wehrli F, Steinbart H. Erfahrungen mit der Haematogenen OxydationsTherapie (HOT). Ars Medici 1954; 10: 44-51.

8. Halliwell B. Free radicals and antioxidants: a personal view. Nutr Rev 1994; 52: 253-265.

9. Wayner DDM, Burton GW, Ingold KU, Barclay LRC, Locke SJ. The relative contributions of vitamin $\mathrm{E}$, urate, ascorbate and proteins to the total peroxyl radical-trapping antioxidant activity of human blood plasma. Biochim Biophys Acta 1987; 924: 408-419.

10. Cross CE, van der Vliet A, O'Neill CA, Louie S, Halliwell B. Oxidants, antioxidants, and respiratory tract lining fluids. Environ Health Perspect 1994; 102: 185-191.

11. van der Vliet A, O'Neill CA, Eiserich JP, Cross CE. Oxidative damage to ex tracellular fluids by ozone and possible protective effects of thiols. Arch Biochem Biophys 1995; 321: 43-50.

12. Wayner DDM, Burton GW, Ingold KU, Locke S. Quantitative measurement of the total, peroxyl radical-trapping antioxidant capability of human blood plasma by controlled peroxidation. FEBS Lett 1985; 187: $33-37$.

13. Cross CE, Reznick AZ, Packer L, Davis PA, Suzuki YJ, Halliwell B. Oxidative damage to human plasma proteins by ozone. Free Rad Res Comms 1992; 15: 347-352.

14. O'Ne ill CA, van der Vliet A, Hu M-L, et al. Oxidation of biologic molecules by ozone: the effect of pH. J Lab Clin Med 1993; 122: 497-505.
15. Halliwell B. Antiox idants in human health and disease. Annu Rev Nutr 1996; 16: 33-50.

16. Bocci V, Paulesu L. Studies on the biological effects of ozone 1. Induction of interferon gamma on human leucocytes. Haematologica 1990; 75 $510-515$.

17. Paulesu L, Luzzi E, Bocci V. Studies on the biological effects of ozone: 2 . Induction of tumor necrosis factor (TNF- $\alpha$ ) on human leucocytes. Lymphokine Cytokine Res 1991; 10: 409-412.

18. DeForge LE, Fantone JC, Kenney JS, Remick DG. Oxygen radical scavengers selectively inhibit interleukin 8 production in human whole blood. J Clin Invest 1992; 90: 2123-2129.

19. Jaspers I, Flescher E, Chen LC. Ozone-induced IL-8 expression and transcription factor binding in respiratory epithelial cells. Am J Physio 1997; 272: L504-L511.

20. Rice-Evans C, Miller NJ. Total antioxidant status in plasma and body fluids. In: Methods in Enzymology. New York: Academic Press, 1994 279-293.

21. Hu M-L. Measurement of protein thiol groups and glutathione in plasma. Methods Enzymol 1994; 233: 380-385.

22. Buege JA, Aust SD. Microsomal lipid peroxidation. Methods Enzymol 1994; 233: 302-310.

23. Bocci V, Valacchi G, Corradeschi F, et al. Studies on the biological effects of ozone: 7. Generation of reactive oxygen species (ROS) after exposure of human blood to ozone. J Biol Regulat Homeost Agent 1998; 12: $67-75$.

24. Pryor WA. Ozone in all its reactive splendor. J Lab Clin Med 1993; 122: 483-486.

25. Los M, Dröge W, Stricker K, Baeuerle PA, Schulze-Osthoff K. Hydrogen peroxide as a potent activator of T lymphocyte functions. Eur Im munol 1995; 25: 159-165.

26. Suzuki YJ, Forman HJ, Sevanian A. Oxidants as stimulators of signal transduction. Free Radical Biol Med 1997; 22: 269-285.

27. Pryor WA, Squadrito GL, Friedman M. The cascade mechanism to ex plain ozone toxicity: the role of lipid ozonation products. Free Radical Biol Med 1995; 19: 935-941.

28. De Groote D, Zangerle PF, GevaertY, et al. Direct stimulation of cytokines (IL-1 $\beta$, TNF- $\alpha$, IL-6, IL-2, IFN- $\gamma$ and GM-CSF) in whole blood. I. Comparison with isolated PBMC stimulation. Cytokine 1992; 4: 239-248.

29. Goldste in BD, Balchum OJ. Effect of ozone on lipid peroxidation in the red blood cell. Proc Soc Exp Biol Med 1967; 126: 356-359.

30. Freeman BA, Mudd JB. Reaction of ozone with sulfhydryls of human erythrocytes. Arch Biochem Biophys 1981; 208: 212-220.

ACKNOWLEDGEMENTS. This w ork w as partially supported by MURST (local, $60 \%$ and national, $40 \%$ ) funds. The careful work of Mrs Helen Carter and Mrs Patrizia Marrocchesi in preparing the manuscript is gratefully acknow ledged.

\section{Received 18 June 1998; \\ accepted in revised form 21 July 1998}




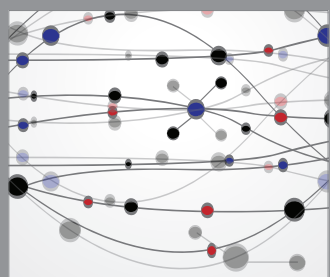

The Scientific World Journal
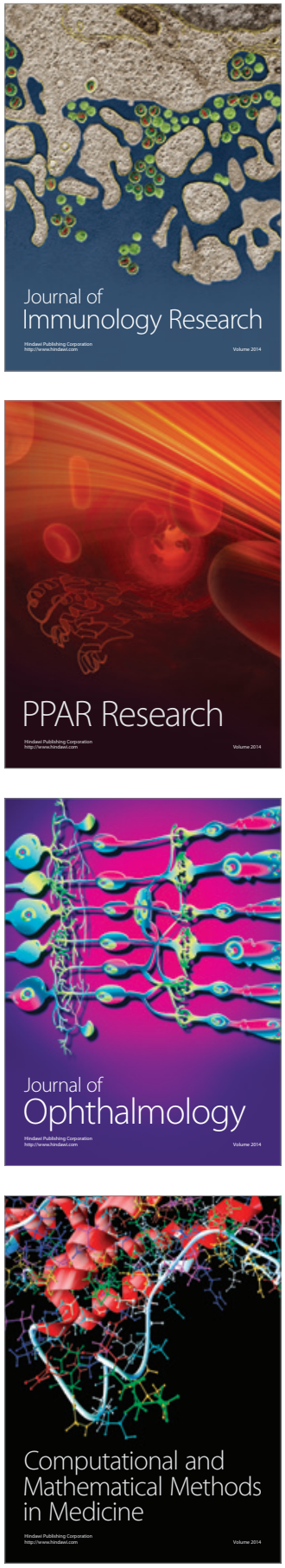

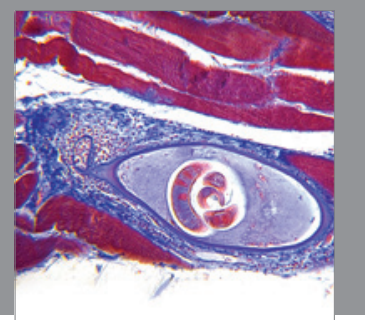

Gastroenterology

Research and Practice
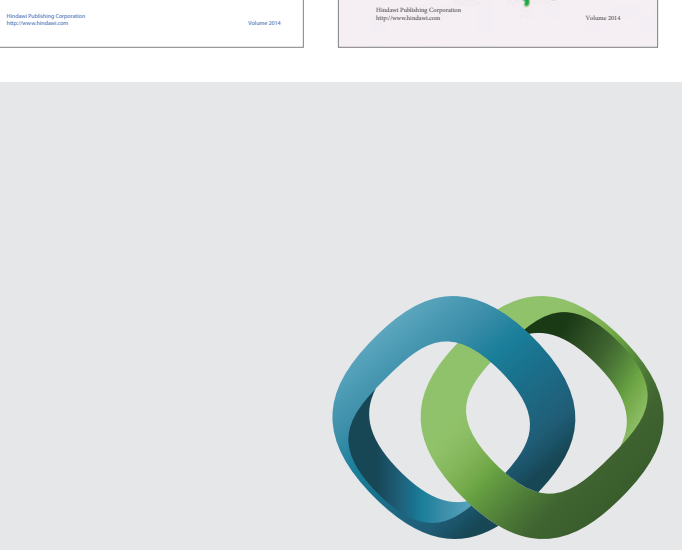

\section{Hindawi}

Submit your manuscripts at

http://www.hindawi.com
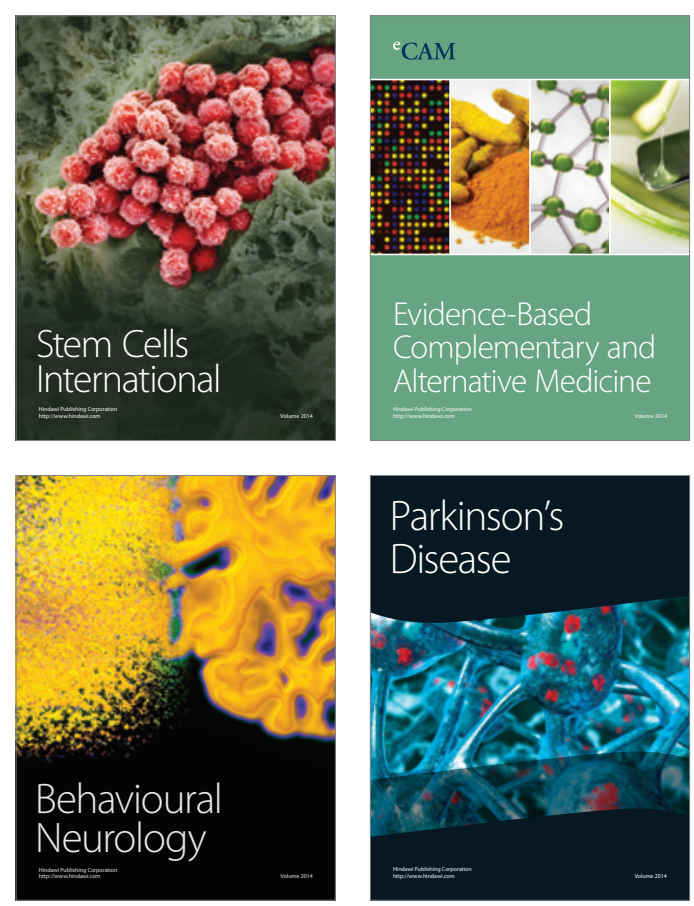

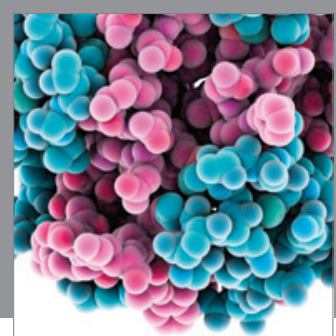

Journal of
Diabetes Research

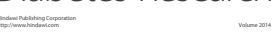

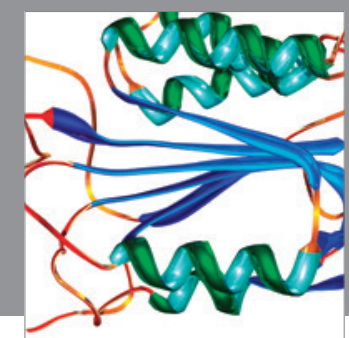

Disease Markers
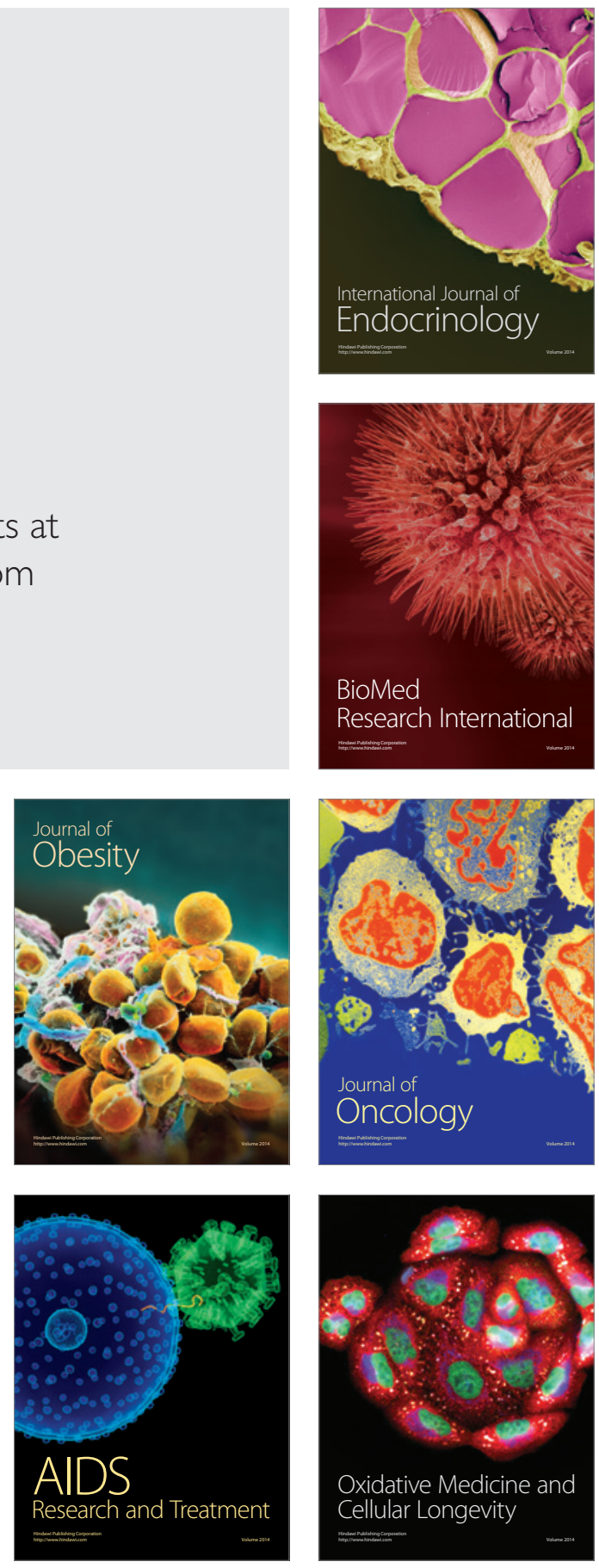